\title{
PENGARUH JUMLAH DAN SEBARAN GCP PADA PROSES REKTIFIKASI CITRA WORLDVIEW II (Studi Kasus : Kota Kediri, Jawa Timur)
}

\author{
INFLUENCE OF THE NUMBER AND DISTRIBUTION GCP FOR RECTIFICATION WORLDVIEW II IMAGERY \\ (A case study : Kediri City, East Java)
}

\author{
Akbar Kurniawan ${ }^{1}$, Muhammad Taufik ${ }^{1}$, Imam Satria Yudha ${ }^{1}$ \\ ${ }^{1}$ Jurusan Teknik Geomatika, Fakultas Teknik Sipil dan Perencanaan \\ Institut Teknologi Sepuluh Nopember Surabaya (ITS) \\ Jl. Arief Rahman Hakim, Surabaya 60111 Indonesia \\ Email: akbar.geodesy@gmail.com
}

\begin{abstract}
Abstrak
Pada penelitian ini dilakukan uji coba penggunaan titik kontrol tanah (GCP) secara variatif, yang terbagi menjadi 5 model jumlah dan distribusi titik kontrol tanah yaitu model 1 dan model 2 menggunakan jumlah 4 GCP dengan pola distribusi pada model 1, GCP hanya terpusat di suatu tempat, tidak menyebar pada keseluruhan citra, sedangkan pada model 2, GCP terletak pada titik terluar citra. Model 3 dan model 4 menggunakan jumlah 8 GCP, dengan pola distribusi pada model 3 titik tersebar merata pada seluruh citra, baik dipinggir maupun ditengah citra, dan pada model 4, GCP terpusat di tengah citra, tidak mencakup pinggir citra. Model 5 merupakan representasi dari model 1 sampai model 4 dengan menggunakan 12 GCP. Hasil penelitian menunjukkan bahwa banyaknya GCP yang digunakan dalam proses rektifikasi citra sangat berpengaruh terhadap ketelitian hasil rektifikasi yang ditunjukkan melalui harga Root Mean Square Eror (RMSE) hasil uji ketelitian jarak dan koordinat. Melalui uji ketelitian ini maka dapat diperoleh skala peta setiap model, yaitu pada model 1 dapat memenuhi skala 1:5000, model 2 skala 1:6000, model 3 skala 1:5000, model 4 skala 1:3000 dan model 5 skala 1:3000.
\end{abstract}

Kata Kunci: citra resolusi tinggi, GCP, penginderaan jauh, rektifikasi

\begin{abstract}
In this study testing the use of ground control points (GCP) is varied, which is divided into 5 model number and distribution of ground control points that model 1 and model 2 uses the number 4 GCP with the distribution pattern of the model 1, GCP is concentrated in one place, did not spread to the entire image, whereas in model 2, GCP is located at the outermost point of the image. Model 3 and model 4 using a number 8 GCP, with the distribution pattern of the model 3 points spread evenly on the entire image, both the edge and the middle of the image, and the model 4, GCP centered in the middle of the image, does not cover the edge of the image. Model 5 is a representation of the model 1 to model 4 using 12 GCP. The results showed that the number of GCP that used in the process of rectifying the image. Affects the accuracy of the rectification results that shown by the price of the Root Mean Square Error (RMSE) obtained from accuracy test of distance and coordinate range. Through this, the accuracy test can be obtained scale map of each model. Model 1 can meet the scale 1: 5000, model 2 scale 1: 6000, model 3 scale 1: 5000, model 4 scale 1: 3000, and model 5 can meet the scale 1:3000.

Keywords: GCP, High Resolution Satellite Image, Rectification, Remote Sensing
\end{abstract}




\section{PENDAHULUAN}

\section{Latar Belakang}

Kota Kediri memiliki bentuk topografi kota yang unik karena sebagian besar wilayah Kota Kediri $(80,17 \%)$ merupakan dataran rendah dengan ketinggian 63-100 meter di atas permukaan laut yang terletak di sepanjang sisi Sungai Brantas. Sedangkan sisanya $(18,83 \%)$ merupakan dataran tinggi dan perbukitan dengan ketinggian $100-500$ meter di atas permukaan laut yang tersebar di bagian barat dan timur Kota Kediri (Bappeda Provinsi Jawa Timur, 2013). Dengan keadaan topografi yang seperti ini dibutuhkan alternatif pemetaan yang tepat dan tidak membutuhkan waktu yang lama yakni dengan teknologi penginderaan jauh.

Dimana teknologi penginderaan jauh adalah suatu pengamatan obyek suatu daerah tanpa melalui kontak langsung dengan obyek tersebuttersebut (Lillesand, dkk, 2004). Penginderaan jauh mampu menghasilkan citra beresolusi tinggi. secara umum, data citra satelit resolusi tinggi juga perlu dilakukan beberapa tahapan pengolahan antara lain image enhancement, mozaicking, dan koreksi geometrik. Tujuan koreksi geometrik yaitu untuk melakukan rektifikasi (pembetulan) atau retorasi (pemulihan) citra agar koordinat sesuai dengan koordinat geografis(Purwadhi,2001). Proses rektifikasi membutuhkan koordinat GCP sebagai data input

Titik kontrol tanah atau GCP (Ground Control Point) memiliki peran penting untuk mengkoreksi data dan memperbaiki keseluruhan citra. Tingkat akurasi titik kontrol tanah sangat bergantung pada jenis GPS yang digunakan dan jumlah sampel titik terhadap lokasi dan waktu pengambilan (Hasyim, 2009). Dalam penelitian ini akan dilakukan analisa pendistribusian dan jumlah titik kontrol tanah dalam proses rektifikasi citra resolusi tinggi. Diharapkan dari penelitian ini akan diketahui model distribusi dan jumlah titik kontrol tanah yang minimum dengan memenuhi toleransi dalam proses rektifikasi.

\section{METODOLOGI PENELITIAN Data Dan Peralatan \\ - Data}

Data yang digunakan dalam penelitian ini adalah citra satelit resolusi tinggi Worldview-2 tahun 2014 dan data hasil pengukuran Ground Control Point (GCP).

\section{- Peralatan}

Peralatan yang digunakan dalam penelitian ini adalah:
1. Perangkat Keras
- Laptop
- GPS Geodetik Topcon HiperPro

2. Perangkat Lunak

- System Operasi Windows 7

- Software pengolah citra satelit

- Software pengolah data GPS

\section{Lokasi Penelitian}

Lokasi penelitian ini dilakukan di Kota Kediri, Jawa Timur. Dimana koordinat kota ini terletak pada $7^{\circ} 46^{\prime} 11^{\prime \prime}-7^{\circ} 52^{\prime} 29^{\prime \prime}$ LS dan $111^{\circ} 57^{\prime} 11^{\prime \prime}$ $112^{\circ} 04^{\prime} 52$.

Secara administratif, Kota Kediri memiliki luas sebesar $63,404 \mathrm{~km}^{2}$ yang terdiri dari 3 kecamatan. Wilayah Kota Kediri berbatasan dengan wilayah Kecamatan Kabupaten Kediri adalah sebagai berikut :

- Sebelah Utara : Kecamatan Gampengrejo dan Kecamatan Banyakan

- Sebelah Selatan :Kecamatan Kandat, Kecamatan Ngadiluwih, dan Kecamatan Semen

- Sebelah Timur : Kecamatan Wates dan Kecamatan Gurah

- Sebelah Barat : Kecamatan Banyakan dan Kecamatan Semen

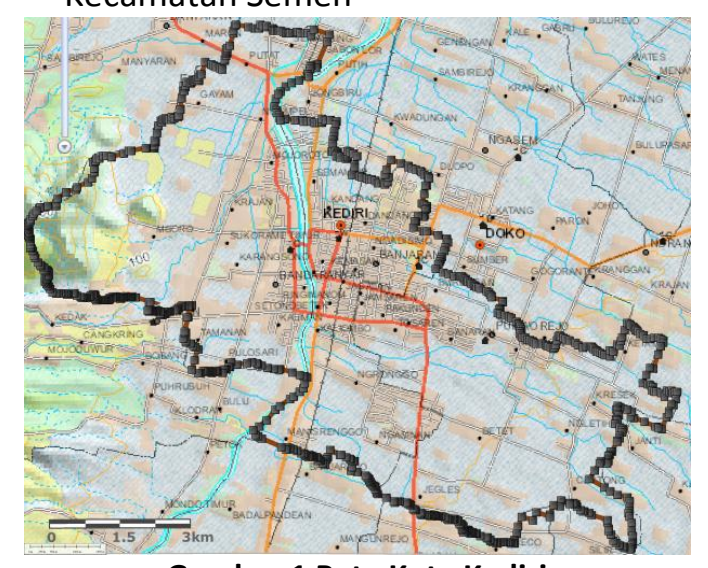

Gambar 1 Peta Kota Kediri

(Sumber : Ina-Geoportal, 2015) 


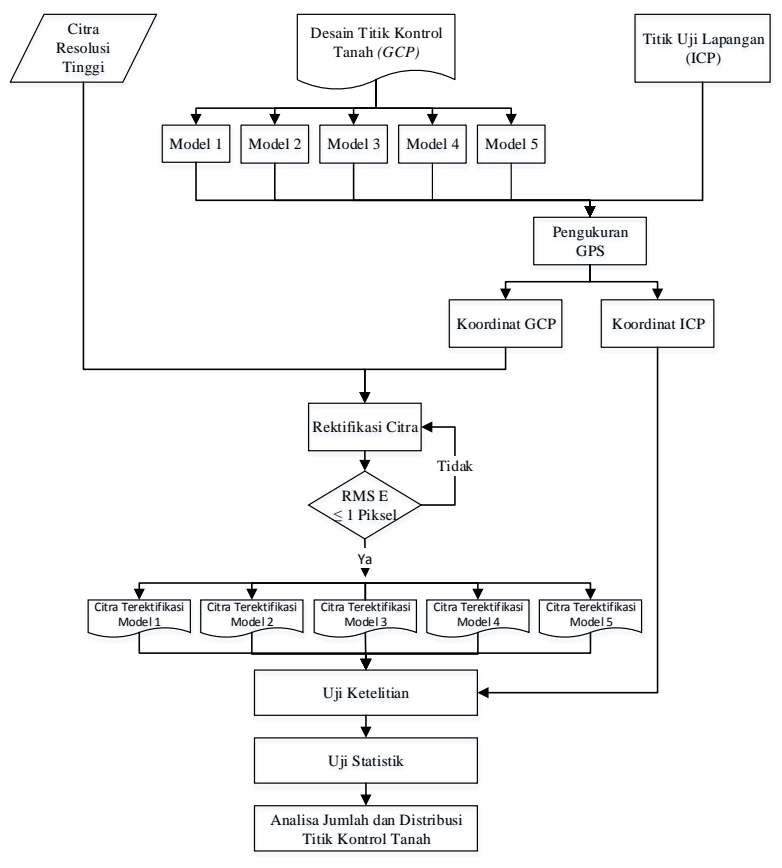

Gambar 2. Diagram Alir Pengolahan Data (Sumber: Hasil Pengolahan)

\section{Pengolahan Data}

Pada tahap pengolahan data (gambar 2) terdapat beberapa thapan yaitu :

1. Data

Data yang digunakan dalam penelitian ini adalah data citra satelit resolusi tinggi Worldview-II Level 1 Tahun 2014. Citra tersebut masih menggunakan sistem koordinat geografis dan belum terproyeksi UTM maka dilakukan proses rektifikasi citra.

2. Pembuatan Desain Titik Kontrol Tanah

Pada tahapan ini dilakukan pembuatan desain jumlah dan distribusi GCP yang akan disebar di citra untuk proses rektifikasi citra. Terdapat 5 model jumlah dan distribusi titik kontrol tanah yaitu model 1 dan model 2 menggunakan jumlah 4 GCP dengan pola distribusi pada model 1, GCP hanya terpusat di suatu tempat, tidak menyebar pada keseluruhan citra, sedangkan pada model 2 GCP terletak pada titik terluar citra. Model 3 dan model 4 menggunakan jumlah $8 \mathrm{GCP}$, dengan pola distribusi pada model 3 titik tersebar merata pada seluruh citra, baik dipinggir maupun ditengah citra, dan pada model 4, GCP terpusat di tengah citra, tidak mencakup pinggir citra. Model 5 merupakan representasi dari model 1 sampai model 4 dengan menggunakan 12 GCP.

3. Pengukuran GPS

Setelah terdapat desain GCP dan titik ICP yang akan digunakan untuk proses rektifikasi citra dan uji lapangan maka dilakukan pengukuran GPS terhadap titik GCP dan ICP tersebut. Pada pengukuran GCP menggunakan metode statik radial dengan durasi pengamatan GPS 60 menit. Terdapat dua metode pada pengukuran ICP yaitu statik singkat dan RTK (Real Time Kinematic).

4. Rektifikasi Citra

Rektifikasi citra bertujuan untuk mereduksi distorsi geometrik dari objek permukaan bumi yang ada pada citra yang diakibatkan oleh kelengkungan permukaan bumi dan beberapa faktor lain seperti variasi tinggi satelit, ketegakan satelit dan kecepatannya, sehingga posisi spasial dari suatu area pada citra sesuai dengan posisi sebenarnya di lapangan. Pada penelitian ini, proses rektifikasi citra dilakukan menggunakan rumus transformasi polinomial orde 1 (linear) terhadap 5 model yang akan diteliti.

5. Hasil Rektifikasi Citra

Masing-masing metode memiliki syarat dalam penentuan kuantitas GCP yang berbeda, namun kelima model harus memenuhi syarat RMSE (Root Mean Square Error) $\leq 1$ piksel (Purwadhi, 2001). Apabila nilai RMSE melebihi 1 piksel, maka harus dilakukan rektifikasi ulang.

6. Citra Terektifikasi

Citra yang telah direktifikasi kemudian dianalisis untuk mendapatkan jumlah dan distribusi yang ideal.

7. Uji Ketelitian

Uji ketelitian dilakukan untuk mengetahui perbedaan data ukuran lapangan dengan data ukuran pada citra hasil rektifikasi. Uji ketelitian dilakukan menggunakan koordinat ICP dan jarak, yang tingkat ketelitiannya diketahui dari besar atau tidaknya nilai RMS eror koordinat atau RMS eror jarak tersebut. Uji ketelitian juga dilakukan pada suatu luasan, misalnya luasan petak sawah, bangunan GOR dan jembatan, untuk mengetahui perbedaan 
luasan hasil pengukuran lapangan dan dijitasi citra terektifikasi diwakili dengan presentse selisih luasan pada citra dengan data lapangan.

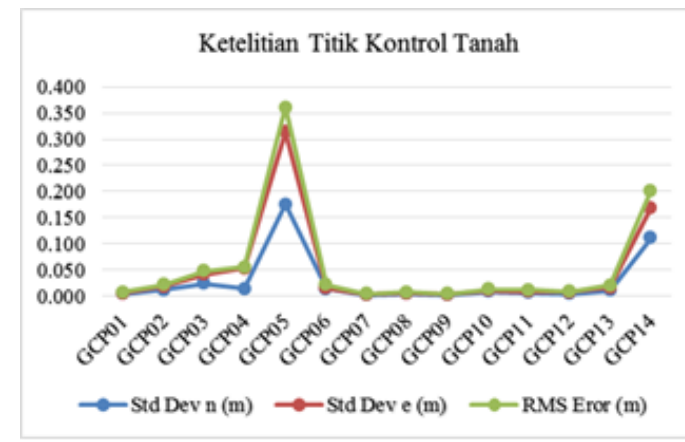

Gambar 3 Grafik Ketelitian Posisi Horizontal Titik Kontrol Tanah

(Sumber: Hasil Pengolahan)

8. Uji Statistik

Uji statistik t-test,digunakan untuk mengetahui model mana yang paling akurat. Dimana t-test adalah uji komparasi antar 2 sampel bebas (independent). Tes ini diterapkan jika analis data bertujuan untuk mengetahui apakah 2 kelompok sampel berbeda dalam variable tertentu. Uji t-test dilakukan pada sampel jarak.

9. Analisis Jumlah dan Model Distribusi Titik Kontrol Tanah

Pada tahapan ini dilakukan analisis sebagai berikut :

a.Analisis pemilihan lokasi GCP

b.Analisis penentuan jumlah dan distribusi GCP.

c.Analisis ketelitian titik hasil pengukuran GPS baik GCP dan ICP.

d.Analisis hasil rektifikasi citra setiap model.

e.Analisis uji ketelitian koordinat, jarak dan luasan.

f.Analisis ketelitian planimetris

Dalam SNI 19-6502.1-2000 tentang spesifikasi penyajian peta rupa bumi Indonesia dinyatakan $0.3 \mathrm{~mm}$ RMS eror yang merupakan nilai koordinat diskalakan terhadap garis grid terdekat dibandingkan dengan hasil koordinat pengukuran di lapangan. Dari ketentuan ini ketelitian planimetris setiap skala peta adalah sebagai berikut :
- Peta skala 1 : 1000 memiliki ketelitian 0.3 $\mathrm{m}$

-Peta skala 1 : 5000 memiliki ketelitian 1.5 $\mathrm{m}$

-Peta skala 1: 10.000 memiliki ketelitian 3 $\mathrm{m}$

g.Analisis statistik untuk menguji tingkat ketelitian pada masing-masing model jumlah dan distribusi

\section{HASIL DAN PEMBAHASAN}

\section{Hasil Pengukuran GPS}

Pengukuran GCP (Ground Control Point) dan ICP (Independent Control Point) menggunakan GPS geodetik dual frekuensi. Pengukuran GCP secara differencial menggunakan metode statik dengan durasi pengukuran 45 menit - 60 menit (tergantung jarak baseline), baseline terbentuk antara BM BIG dengan GCP yang diukur. ICP diukur dengan metode rapid static (statik singkat) dengan durasi pengukuran 10 menit - 20 menit. Selain metode statik singkat untuk pengukuran ICP juga menggunakan metode RTK (Real Time Kinematic).

Hasil dari pengukuran GCP (gambar 3) diperoleh nilai residual titiknya antara 0,005 $\mathrm{m}$ sampai 0,360 m. Dari titik tersebut ketelitian tertinggi pada titik GCP 07 dan ketelitian terendah pada titik GCP 05 . Nilai residual diakibatkan oleh noise sinyal GPS yaitu multipath dan cyle slips.

\section{Hasil Rektifikasi Citra}

Tabel 1 RMS Eror Hasil Rektifikasi Citra

\begin{tabular}{ccc}
\hline No. & Model & Rata-rata RMS eror \\
\hline 1 & Model 1 & 0,354 \\
2 & Model 2 & 0,637 \\
3 & Model 3 & 0,544 \\
4 & Model 4 & 0,525 \\
5 & Model 5 & 0,373 \\
\hline
\end{tabular}

Proses rektifikasi menggunakan polynomial orde 1 yaitu linear. Hal ini diberlakukan sama pada setiap model karena pada polynomial orde 1 minimal dibutuhkan 3 GCP untuk melakukan proses rektifikasi, polynomial orde 2 membutuhkan minimal 6 GCP dan pada orde 3 membutuhkan minimal $10 \mathrm{GCP}$, sehingga pada penelitian ini pemilihan polynomial orde 
1 sangatlah tepat karena bisa diberlakukan untuk semua model.

Terdapat beberapa faktor dalam pemilihan orde polynomial yaitu jumlah titik kontrol yang

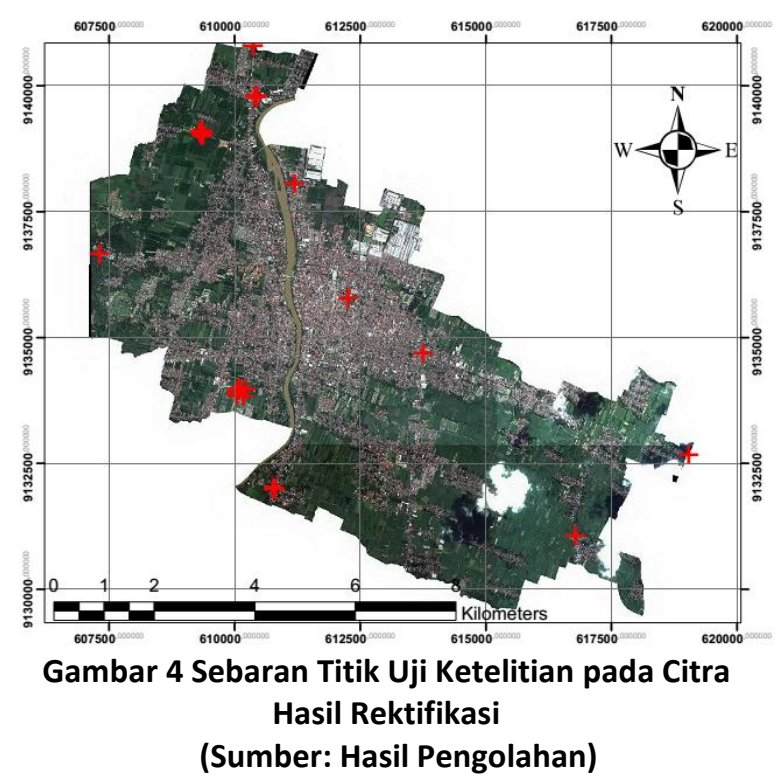

tersedia, keadaan topografi daerah serta kesalahan atau distorsi pada citra yang akan direktifikasi.

Untuk mengetahui akurasi hasil rektifikasi citra dapat dilihat dari nilai RMS eror. Nilai RMS eror menunjukkan nilai kesalahan yang terjadi dalam proses rektifikasi yang telah dilakukan.

\section{Analisis Ketelitian Koordinat Citra}

Analisis ketelitian koordinat diperoleh dengan mencari residu data pengukuran di lapangan yang berupa titik koordinat dari pengukuran GPS dan titik koordinat dari citra satelit setelah proses rektifikasi. Nilai residu koordinat $X$ dan $Y$ digunakan untuk mencari nilai RMS eror koordinat citra.

Jumlah sample yang diambil sebanyak 30 titik, yang terletak di wilayah Kota Kediri. Dari data residu koordinat lapangan dengan koordinat citra hasil rektifikasi dapat diperoleh nilai RMS eror koordinat citra.

Tabel 2 Nilai RMSE Hasil Uji Ketelitian Koordinat Sumber : Hasil Perhitungan

\begin{tabular}{ccc}
\hline No & Model & Rata-rata RMS eror \\
\hline 1 & Model 1 & 2.476 \\
2 & Model 2 & 2.031 \\
\hline
\end{tabular}

\begin{tabular}{lll}
\hline 3 & Model 3 & 1.611 \\
4 & Model 4 & 1.270 \\
5 & Model 5 & 1.718 \\
\hline
\end{tabular}

Dari tabel dan gambar dapat dilihat model 4 memiliki nilai RMS eror koordinat paling kecil yaitu 1,270 meter, model 4 menggunakan 8 GCP dengan model pendistribusian terkumpul pada pusat kota. Setelah model 4 ketelitian koordinat citra hasil rektifikasi terdapat pada model 3 dengan nilai RMS eror koordinat 1,611 meter dan menggunakan 8 GCP dengan model distribusi yang relatif menyebar dan terletak disisi terluar citra.

Pada model 5 nilai RMS eror koordinat citranya adalah 1,718 . Seharusnya model 5 memiliki hasil ketelitian koordinat yang paling baik, karena merupakan representasi dari seluruh model baik dari segi jumlah yaitu 12 GCP dan distribusi yang merata.

\section{Analisis Ketelitian Jarak pada Citra}

Ketelitian objek pada peta citra dilakukan secara komparatif dengan cara membandingkan data hasil pengukuran jarak di peta citra terhadap data hasil pengukuran jarak di lapangan (Rudianto,2011). Ketelitian jarak pada citra dinyatakan dalam nilai RMS eror jarak.

Terdapat 4 sampel jarak yang akan ditentukan ketelitiannya yaitu :

1. Jarak yang terbentang dari utara ke selatan yang diwakili oleh titik GCP11 dan ICP 20.

2. Jarak yang terbentang dari barat ke timur yang diwakili oleh titik GCP09 dan GCP04.

3. Panjang jalan sebelah utara GOR Jayabaya Kediri yang diwakili oleh titik ICPRO2 dan ICP29.

4. Panjang jalan sebelah selatan GOR Jayabaya Kediri yang diwakili titik ICPR12 dan ICPR19.

Analisis ketelitian jarak berfungsi untuk lebih mengetahui apakah ada perbedaan perubahan skala pada sumbu $X$ atau sumbu $Y$ ketika proses rektifikasi atau memiliki perubahan yang sama antara sumbu $X$ dan sumbu $Y$.

Berikut adalah data perbandingan hasil pengukuran jarak pada peta citra dan data hasil pengukuran jarak di lapangan. 


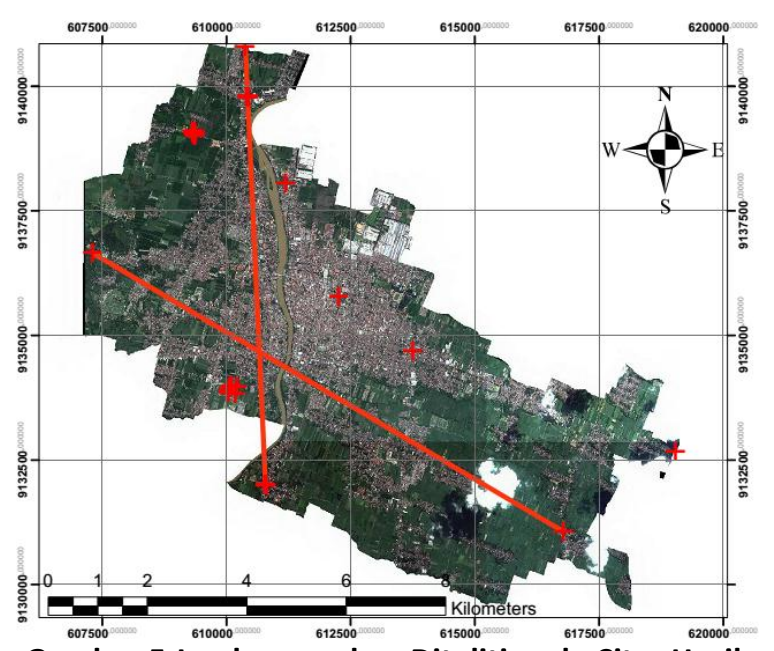

Gambar 5 Jarak yang akan Diteliti pada Citra Hasil Rektifikasi

Tabel 3 Nilai RMSE Hasil Uji Ketelitian Jarak Sumber : Hasil Perhitungan

\begin{tabular}{lc}
\hline Model & \\
& RMS Eror Jarak $(\mathrm{m})$ \\
\hline Model 1 & 1.412 \\
Model 2 & 1.523 \\
Model 3 & 1.399 \\
Model 4 & 0.689 \\
Model 5 & 0.619 \\
\hline
\end{tabular}

Dari tabel 3 dapat dilihat model 4 memiliki nilai RMS eror jarak paling kecil yaitu 0,689 meter, model 4 menggunakan 8 GCP, dan titik yang digunakan untuk uji ketelitian jarak sebagai GCP hanya GCP 09, sedangkan titik untuk pengujian jarak lainnya menggunakan titik GCP dan ICP lainnya. Pada model 5 nilai RMS eror jarak pada citra adalah 0,619 meter, dan titik yang digunakan untuk uji ketelitian jarak sebagai GCP terdapat 3 titik yaitu GCP04, GCP09, dan GCP11 selain itu menggunakan ICP. Faktor yang mempengaruhi RMS eror jarak adalah lebih kepada pemilihan rumus dan identifikasi titik GCP pada proses rektifikasi citra.

\section{Analisis PerbedaanLuasan pada Citra}

Selain didapatkan nilai RMS eror dari koordinat dan jarak dari citra yang terektifikasi dapat juga dihasilkan data luasan atau area dari bidang yang dibatasi oleh koordinat-koordinat tersebut. Luas hasil perhitungan dengan menggunakan ICP memilki selisih yang cukup signifikan dengan luas hasil dari citra terektifikasi. Ketelitian luasan pada citra dinyatakan dengan presentasi dari selisih luasan pada pengukuran dilapangan dengan luasan pada citra terektifikasi.

Terdapat 4 sampel luasan yang akan dipresentasekan perbedaannya :

1. Luas Kota Kediri menggunakan titik-titik terluar GCP ataupun ICP sehingga membentuk suatu poligon luasan.

2. Luas GOR Jayabaya Kediri.

3. Luas petakan sawah.

4. Luas jembatan depan Pabrik Gula Mrican.

Tabel 4 Hasil Presentasi Selisih Luasan Sumber : Hasil Perhitungan

\begin{tabular}{ccc}
\hline No & Model & Rata-rata Selisih Luas \\
\hline 1 & Model 1 & $3.66 \%$ \\
2 & Model 2 & $3.81 \%$ \\
3 & Model 3 & $2.50 \%$ \\
4 & Model 4 & $2.37 \%$ \\
5 & Model 5 & $1.32 \%$ \\
\hline
\end{tabular}

Dari tabel 4 dapat dilihat presentase selisih luas rata-rata paling baik terdapat pada model 5 yaitu 1,32\%, dilanjutkan dengan model 4 sebesar 2,37\%, model 3 sebesar 2,50\%, model 1 sebesar 3,66\% dan pada model 2 sebesar $3,81 \%$. Analisis beda luas dilakukan dengan menggunakan toleransi yang digunakan yaitu sebesar $10 \%$.

\section{Skala Peta}

Dalam SNI 19-6502.1-2000 tentang spesifikasi teknis penyajian peta rupa bumi Indonesia skala 1:10000 dinyatakan pada skala tersebut mempunyai nilai $0.3 \mathrm{~mm}$ RMS eror yang merupakan nilai koordinat yang diskalakan terhadap garis grid terdekat dibandingkan dengan hasil koordinat pengukuran di lapangan.

Dari ketentuan ini ketelitian planimetris setiap skala peta adalah sebagai berikut :

a.Peta skala 1 : 1000 memiliki ketelitian $0.3 \mathrm{~m}$ b.Peta skala 1 : 5000 memiliki ketelitian $1.5 \mathrm{~m}$ c.Peta skala 1: 10.000 memiliki ketelitian $3 \mathrm{~m}$ 
Tabel 5 Skala Peta Hasil Rektifikasi Citra Sumber : Hasil Perhitungan

\begin{tabular}{cccccc}
\hline Model & $\begin{array}{c}\text { RMS Eror } \\
\text { Jarak (m) }\end{array}$ & \multicolumn{3}{c}{ Skala Peta } \\
\hline Model 1 & 1.412 & 1 & $:$ & 5000 \\
Model 2 & 1.523 & 1 & $:$ & 6000 \\
Model 3 & 1.399 & 1 & $:$ & 5000 \\
Model 4 & 0.689 & 1 & $:$ & 3000 \\
Model 5 & 0.619 & 1 & $:$ & 3000 \\
\hline
\end{tabular}

Pada tabel 5 diketahui model 4 dan 5 memenuhi syarat untuk pengadaan peta skala 1:3000 dan untuk model 1 dan model 3 memenuhi syarat untuk pengadaan peta 1:5000, sedangkan untuk model 2 dapat memenuhi syarat untuk pengadaan peta 1:6000.

Sehingga dapat disimpulkan bahwa model 4 dengan 8 GCP dan dengan pola distribusi yang terkumpul ditengah atau di kota mempunyai tingkat ketelitian planimetris, efektifitas waktu dan biaya yang baik dibandingkan dengan model yang lainnya, untuk model 5 juga memenuhi ketelitian yang baik secara planimetris, tetapi jumlahnya yang banyak dan tersebar diseluruh kota membutuhkan waktu dan biaya yang lebih banyak dibandingkan model 4.

Hal ini disebabkan adanya faktor pengurangan jumlah dan distribusi titik kontrol tanah (GCP). Semakin banyak titik kontrol tanah dan model distribusinya merata maka tingkat ketelitian koordinatnya lebih baik. Begitu pula sebaliknya. Karena titik kontrol tanah berfungsi sebagai titik ikat objek-objek di sekitarnya, sehingga ketika titik-titik kontrol tanah itu tidak digunakan maka titik ikat objek objek sekitar GCP yang tidak digunakan itu akan tertarik ke GCP lainnya. Hal itu dapat menyebabkan besarnya nilai RMS eror koordinat citra.

\section{Uji Statistik t-test}

Uji statistik t-test dilakukan untuk menguji apakah tingkat ketelitian jarak pada citra hasil rektifikasi memenuhi ketelitian berdasarakan uji t-test, jarak yang diuji yaitu jarak yang terbentang dari utara ke selatan dan jarak yang terbentang dari barat ke timur, dengan hipotesis yang akan diuji adalah sebagai berikut:

- Ho : Tidak terdapat perbedaan yang signifikan antara hasil pengukuran jarak dari data acuan dengan hasil pengukuran jarak dari dijitasi citra, atau Ho adalah ukuran yang terdapat didalam batas $\mathrm{x} 1 \leq$ $\mu \leq x 2$.

- Ha : Terdapat perbedaan yang signifikan antara hasil pengukuran luas dari data acuan dengan hasil pengukuran jarak dari data acuan dengan hasil pengukuran jarak dari dijitasi citra, atau $\mathrm{Ha}$ merupakan ukuran yang berada di luar batas ukuran yang terdapat pada Ho.

Jika digunakan $\alpha=10 \%$ dan derajat kebebasan $1(\mathrm{n}=2)$, maka didapat :

$\mathrm{t} \gamma, 1 / 2 \alpha=\mathrm{t} 1,0.05=6,313$ (dari tabel student t-test). Dengan metode uji dari dua sisi (two sided test) dihitung :

$\mathrm{X} 1=\mu-((\mathrm{t} 1,0.05 * \sigma \mathrm{x}) / \mathrm{v} 2)$

$=\mu-((6,313 * 0.714) \mathrm{V} 2)$

$\mathrm{X} 2=\mu-((\mathrm{t} 1,0.05 * \sigma \mathrm{x}) / \mathrm{V} 2)$

$=\mu+((6,313 * 0.714) \mathrm{V} 2)$

Dari perhitungan seluruh model dengan $\alpha$ $=10 \%$, terdapat 2 hasil yang berada di luar ukuran yang berarti Ho ditolak (Ha diterima) pada pengujian sampel jarak utara ke selatan pada model 1 dan model 2 .

Tabel 6 Skala Peta Hasil Rektifikasi Citra

Sumber : Hasil Perhitungan

\begin{tabular}{ccccc}
\hline Model & $\mu$ & X1 & X2 & Keterangan \\
\hline Model 1 & 8797.484 & 8789.295 & 8795.669 & Ditolak \\
Model 2 & 8788.953 & 8789.295 & 8795.669 & Ditolak \\
Model 3 & 8789.457 & 8789.295 & 8795.669 & Diterima \\
Model 4 & 8791.901 & 8789.295 & 8795.669 & Diterima \\
Model 5 & 8791.252 & 8789.295 & 8795.669 & Diterima \\
\hline
\end{tabular}

Pada tabel 6 yang merupakan uji t-test untuk jarak utara ke selatan pada model 1 dan model 2 ditolak, karena pengukuran berada diluar batas. Untuk model lainnya yaitu model 3, model 4 dan model 5 Ho diterima.

Berdasarkan uji statistik t-test tingkat kepercayaan $10 \%$ diketahui bahwa tingkat ketelitian planimetris yang baik adalah model 3,model 4 dan model 5 . Hal ini disebabkan 
karena pada model 3 sampai 5 menggunakan 8 dan 12 GCP.

Dapat disimpulkan melalui uji t-test ini untuk jumlah yang optimal dalam proses rektifikasi citra adalah minimal menggunakan 8 GCP.

\section{PENUTUP}

\section{Kesimpulan}

Dari hasil pengolahan dan analisa yang telah dilakukan pada penelitian ini, dapat diambil kesimpulan antara lain:

1. Hasil dari proses rektifikasi citra adalah sebagai berikut :

- Model 1 dengan nilai RMS eror sebesar 0.354

- Model 2 dengan nilai RMS eror sebesar 0.637

- Model 3 dengan nilai RMS eror sebesar 0.544

- Model 4 dengan nilai RMS eror sebesar 0.525

- Model 5 dengan nilai RMS eror sebesar 0.373

2. Hasil uji ketelitian pada koordinat dan jarak menyatakan model 4 yang paling baik, dengan nilai RMS eror koordinat 1,270 meter dan RMS eror jarak 0,689 meter. Model 5 memiliki RMS eror dibawah model 4 yaitu RMS eror koordinat 1,718 dan RMS eror jarak 0,619.

3.Model jumlah dan distribusi yang paling baik terdapat pada model 4 dengan menggunakan 8 GCP dengan pola distribusi yang mengumpul pada tengah kota atau citra.

4. Penggunaan GCP yang berlebihan, tidak meningkatkan harga RMS eror secara signifikan.

5. Skala peta yang dapat dipenuhi pada citra hasil rektifikasi adalah sebagai berikut :

- Model 1 dapat memenuhi skala peta 1 : 5000

- Model 2 dapat memnuhi skala peta 1 : 6000

- Model 3 dapat memenuhi skala peta 1 : 5000

- Model 4 dapat memnuhi skala peta 1 : 3000
- Model 5dapat memenuhi skala peta 1 : 3000

6. Berdasarkan uji statistik t-test dengan $\alpha$ $=10 \%$, untuk jumlah yang optimal dalam proses rektifikasi citra adalah minimal menggunakan 8 GCP dengan pola distribusi titik yang memiliki jarak yang hampir sama diantara titik lainnya.

\section{Saran}

Saran yang dapat diberikan sebagai berikut :

1. Jumlah minimum titik kontrol tanah untuk citra Kota Kediri yang diperlukan yaitu 8 GCP.

2. Pola distribusi titik kontrol tanah sebaiknya dilakukan merata tetapi tidak harus mengutamakan titik terluar citra, diusahakan memiliki jarak yang hampir sama antara titik yang satu dengan titik lainnya.

3. Ketelitian titik GCP dan ICP sebaiknya diamati dan diolah agar memenuhi toleransi.

4. Menggunakan berbagai rumus transformasi pada saat proses rektifikasi citra.

\section{DAFTAR PUSTAKA}

Lilesand, dkk. 2004. Remote Sensing and Image Interpretation. Wisconsin: Wiley.

Bappeda Provinsi Jawa Timur. 2013. kota- kediri2013

Purwadhi, F. S. 2001. Interpretasi Citra Digital.Jakarta:Grasindo.

Hasyim, A. W. 2009. Menentuan Titik Kontrol Tanah (GCP) dengan Menggunakan Teknik GPS dan Citra Satelit untuk Perencanaan Perkotaan.

Rudianto, Bambang. 2011. Analisis Pengaruh Sebaran Ground Control Point Terhadap Ketelitian Objek pada Peta Citra Hasil Ortorektifikasi. 